\title{
Aplikasi Hakikat Teori Belajar Konstruktivisme dalam Pembelajaran Pendidikan Agama Islam
}

\author{
Dinda Dwi Azizah ${ }^{1}$, Fuan Sa'adah ${ }^{2}$ \\ Jurusan Ilmu Agama Islam, Fakultas Ilmu Sosial, Universitas Negeri Padang, Indonesia ${ }^{1,2}$ \\ dindadwiazizahh@gmail.com ${ }^{1}$, fuansaadah29@gmail.com ${ }^{2}$
}

\begin{abstract}
Currently, there are various new innovations in the world of education, especially in the learning process. One such innovation is constructivism. The choice of this approach is because learning makes students face existing problems, so they are willing to try to solve these problems. Learning in the classroom is still dominant by using the lecture method and the question and oanswer method so that it does not provide opportunities for students to interact directly. A teacher must pay attention to students' initial concepts before learning. If this is not the case, then an educator will not succeed in instilling the correct concept, and can even limit the source of further learning difficulties. Teaching is not only for ideas from educators to students, but as a process of changing the existing conceptions of students and where it might be wrong, and if it turns out to be true then educators must be able to help students construct these conceptions to make them more mature. The author becomes interested in conducting this research to find out how the true nature of constructivist learning theory can develop student activeness in constructing their own knowledge.
\end{abstract}

Keywords: Applications, Constructivism, Islamic Education.

\section{Pendahuluan}

Indonesia memiliki sistem pendidikan dalam konteks kehidupan bangsa dan bernegara yaitu sistem pendidikan nasional, yang berfungsi untuk mengembangkan kemampuan dan membentuk watak serta peradaban bangsa yang bermartabat dalam rangka mencerdaskan bangsa dan mewujudkan tujuan nasional. Hal tersebut berhubungan dengan paradigma pendidikan yaitu suatu pemikiran yang mendasar tentang pendidikan. Perkembangan paradigma di Indonesia saat ini pun sudah mengalami perkembangan, salah satu realitas pembelajaran di Indonesia sekarang sudah menerapkan teori belajar konstruktivisme. Paradigma konstruktivisme berakar pada filsafat humanisme dan fenomenologi. Perkembangan dalam paradigma ini juga mengambil sejumlah gagasan yang dikembangkan oleh teori belajar kognitif (Yusuf, 2004). 
Ide-ide pendidikan konstruktivis adalah "semua pelajar benar-benar mengkonstruksikan pengetahuan untuk dirinya sendiri, dan bukan pengetahuan yang datang dari guru diserap oleh murid (Muijs dan Reynolds, 2008). Hal ini menunjukkan bahwa paradigma konstruktivisme merupakan suatu tuntutan baru di tengah terjadinya perubahan besar dalam mamaknai proses pendidikan dan pembelajaran. Pergeseran paradigma pembelajaran yang sebelumnya lebih menitikberatkan pada peran guru, fasilitator, instruktur yang demikian besar, dalam perjalanannya semakin bergeser pada pemberdayaan siswa dalam mengambil inisiatif dan partisipasi saat kegiatan belajar. Tugas guru dengan demikian adalah memahami fakto-faktor intrinsik yang ada dalam diri siswa. Menciptakan situasi pembelajaran yang menarik dan kondusif, bukan semata tugas guru. Paradigma behavioristik mempunyi tugas untuk menciptakan lingkungan pembelajaran yang kondusif adalah tugas guru. Guru harus bisa menciptakan alat reinforcement yang bagus. Sebaliknya, dalam paradigma konstruktivistik, siswa juga memiliki potensi intrinsik dalam menciptakan lingkungan belajar yang kondusif.

Teori belajar konstruktivisme sangat relevan untuk perkembangan pembelajaran di Indonesia, karena teori ini mempunyai keunggulan yang dapat digunakan sebagai metode belajar yang inovatif. Keunggulan dalam teori konstruktivisme adalah dapat membentuk siswa untuk membangun pemahamannya dalam belajar melalui proses asimilasi, akomodasi, dan ekuilibrasi, hal ini karena teori ini masih berkaitan dengan teori belajar kognitif (Trianto 2007). Teori konstruktivisme juga memiliki keunggulan seperti: menekankan pada proses pembelajaran daripada materi pembelajaran, motivasi dan kepuasan datang dari siswa, bukan hanya meningkatkan skill tetapi pemikiran dan pemahaman siswa, mendorong tumbuhnya kemampuan belajar siswa dengan sendiri dan tanggung jawab (Trianto, 2007).

Terjadinya kenaikan hasil belajar siswa juga penting untuk mengukur tingkat pemahaman siswa setelah dilakukannya perlakuan dari awal penelitian sampai akhir penelitian. Hasil belajar merupakan puncak dari proses belajar (Anni, 2007) Menerapkan teori belajar konstruktivis dalam proses pembelajaran dapat meningkatkan keaktifan sehingga berpengaruh terhadap hasil belajar siswa. Cara lain untuk memberikan motivasi kepada siswa dalam meningkatkan hasil belajar, salah satunya dengan menggunakan media sebagai pendukung metode belajar konstruktivisme yang diterapkan.

Media pembelajaran merupakan alat bantu yang dapat digunakan oleh guru kepada siswa dalam memberikan suatu materi pembelajaran, sehingga tercipta suasana belajar-mengajar yang efektif dan efisien. Asosiasi Pendidikan Nasional (National Education Association/NEA) mengemukakan bahwa media merupakan bentuk-bentuk komunikasi baik dalam bentuk cetak maupun audiovisual beserta peralatannya (dalam Sadiman dkk, 2008). Pembelajaran konstruktivisme yang diterapkan media dapat mendukung pembelajaran dalam memotivasi siswa.

\section{Tinjauan Pustaka}

Tinjauan Pustaka dimaksudkan untuk mengemukakan teori-teori yang relevan dengan masalah yang akan diteliti. Tinjauan pustaka dengan demikian akan menjadi dasar pemikiran dalam penyusunan penelitian ini. Teori pembelajaran konstruktivistik dapat meningkatkan hasil belajar. Teori pembelajaran konstruktivistik mejadikan peserta didik tidak hanya menerima materi pembelajaran dari guru, namun peserta didik juga yang berusaha untuk menggali dan mengembangkannya sendiri. Teori pembelajaran konstruktivisme dalam hal ini tidak hanya menghasilkan dan meningkatkan pengetahuan saja, tetapi teori ini juga dapat meningkatkan keterampilan berpikir kritis peserta didik. Teori pembelajaran konstruktivistik mampu meningkatkan hasil belajar peserta didik. Hasil belajar diperoleh dari kemampu- an peserta didik 
dalam memecahkan masalah dalam soal yang dikerjakan secara mandiri maupun kelompok. Kemampuan peserta didik untuk memecahkan masalah tersebut dapat dilihat dari kemampuanya dalam menjelaskan hasil pekerjaanya di depan kelas dan menjawab pertanyaan-pertanyaan yang diajukan oleh teman-temanya.

Teori konstruktivistik menerapkan pembelajaran yang menekan pada keaktifan dan keterlibatan peserta didik dalam proses pembelajaran sebagai pening- katan hasil belajar yang optimal. Aplikasi Teori Belajar Konstruktivisme bila diterapkan di kelas akan terbentuk: a) Mendorong kemandirian dan inisiatif siswa dalam belajar. b) Guru mengajukan pertanyaan terbuka dan memberikan kesempatan beberapa waktu kepada siswa untuk merespon. c) Mendorong siswa berpikir tingkat tinggi. d) Siswa terlibat secara aktif dalam dialog atau didkusi dengan guru dan siswa lainnya. e) Siswa terlibat dalam pengalaman yang menantang dan mendorong terjadinya diskusi. f) Guru memberika data mentah, sumber-sumber utama, dan materi-materi interaktif.

\section{Metode Penelitian}

Metode yang digunakan oleh peneliti dalam penelitian ini adalah kualitatif, dengan menggunakan teknik pengumpulan data observasi, wawancara, dan dokumentasi. Proses kajian yang ada di dalamnya adalah review jurnal yaitu dengan mengkaji beberapa jurnal yang berkaitan dengan teori pembelajaran konstruktivistik. Review jurnal merupakan analisis dan memberikan ulasan terhadap sebuah artikel jurnal, merangkum dan mengidentifikasi kelebihan dan kekurangan artikel tersebut. Sumber data yang digunakan pada review jurnal tentang teori pembelajaran konstruktivistik ini adalah data sekunder.

Strategi pencarian data yang digunakan adalah mencari langsung jurnal melalui pencarian online dengan melihat jurnal yang sudah ada lalu mencari sumber dalam review jurnal tersebut untuk dimasukkan dalam review jurnal ini. Tahap analisis data kualitatif membaca/mempelajari data, menandai dan gagasan yang ada dalam data; Mempelajari kata-kata kunci itu, berupaya menemukan tema-tema yang berasal dari data; Koding atau pengodean; Menuliskan 'model' yang ditemukan; Visualisasi adalah usaha sesorang untuk mengembangkan sesuatu benda atau suatu keadaan dan kejadian di dalam pikiranya (Satori \& Komariah, 2012:22).

\section{Hasil dan Pembahasan}

\section{Teori Konstruktivistik dalam Pembelajaran Agama Islam}

Penerapan teori pembelajaran konstruktivistik selalu menjadi pendekatan yang berhasil untuk meningkatkan hasil belajar dikarenakan teori konstruktivisme merupakan teori yang memberikan keluasan berfikir kepada peserta didik serta pemahamanya tentang teori yang sudah diketahuinya dalam kehidupanya. Hill mengungkapkan bahwa teori konstruktivisme menghasilkan sesuatu dari apa yang dipelajarinya, dengan kata lain bahwa dengan memadukan suatu pembelajaran dengan melakukanya atau mempraktikanya dalam kehidupannya. Shymansky menjelaskan konstruktivisme adalah aktivitas yang aktif, dimana siswa membangun sendiri pengetahuanya dan kerangka berfikir yang telah dimilikinya. Pernyataan ini juga sesui dengan apa yang diungkapkan oleh Moshman, bahwa pengetahuan itu berasal dari merefleksikan dan mengkoordinasikan kognisi atau pikiran kita sendiri, bukan dari memetakan realitas eksternal (Supardan, 2016).

Pendapat diatas dapat dipahami bahwa teori konstruktivistik merupakan teori yang dapat mengaktifkan proses pembelajaran peserta didik dengan mengandalkan pengalaman awal peserta didik untuk mengkonstruksi atau membangun pengetahuannya sendiri, meskipun pendekatan pembelajaran ini membutuhkan waktu yang cukup lama untuk mengkonstruksi pengetahuan peserta didik. Hal ini dikarenakan pola pikir setiap individu itu berbeda-beda ada 
yang cepat mengkonstruksi atau memahami apa yang dijelaskan atau ditanyakan oleh guru dan adapun yang lambat untuk mengkonstruksi apa yang sudah guru jelaskan.

Teori pembelajaran konstruktivisme pada pembelajaran di kelas muncul dalam 5 langkah berikut, yaitu, (1) pengaktifan yang sudah ada (activating knowledge); (2) pemerolehen pengetahuan baru (acquiring knowledge) di lakukan secara keseluruhan, tidak dalam paketpaket tersisah; (3) pemahaman pengetahuan baru (understading knowledge) dalam memahami pengetahuan belajar, menyelidiki dan menguji semua hal yang memungkinkan dari pengetahuan baru itu; (4) menerapkan pengetahuan dan pengalaman yang diperoleh (applying knowledge), peserta didik memerlukan waktu untuk memperluas dan memperhalus struktur pengetahuannya dengan cara menggunakannya secara autentik melalui penyelesaian atau pemecahan masalah; dan 5) melakukan refleksi (reflecting on knowledge), jika pengetahuan sepenuhnya dipahami dan diterapkan secara luas, maka pengetahuan itu dikontekstualkan dan hasil ini memerlukan refleksi (Kusuma \& Nisa, 2019).

Uraian di atas dapat kita ketahui bahwa semakin banyak pengetahuan awal yang dimiliki peserta didik baik dari segi kebenaran maupun hubungan dengan pengetahuan baru yang dimiliki oleh peserta didik, maka semakin banyak pula pemahaman dengan pengetahuan yang dimiliki dan semakin sedikit pengetahuan yang relavan, maka semakin sulit pula peserta didik dalam memahami pengetahuan baru.

Hakikat pembelajaran menurut teori Konstruktivistik adalah suatu proses pembelajaran yang mengkondisikan peserta didik untuk melakukan proses aktif membangun konsep baru, pengertian baru, dan pengetahuan baru berdasarkan data. Oleh karena itu, proses pembelajaran harus dirancang dan dikelola sedemikian rupa sehingga mampu mendorong peserta didik mengorganisasi pengalamannya menjadi pengetahuan yang bermakna.

Konstruktivistik ini memiliki peran penting pada peserta didik untuk membangun constructive habits of mind. Agar peserta didik memiliki kebiasaan berpikir, maka dibutuhkan kebebasan dan sikap belajar. Teori belajar yang mencerminkan peserta didik memiliki kebebasan artinya peserta didik dapat memanfaatkan teknik belajar apa pun asal tujuan belajar dapat tercapai.

Berdasarkan jenis materinya, mata pelajaran Pendidikan Agama Islam termasuk mata pelajaran yang bersifat teoritis-praktis, dengan tekanan utama penyerapan peserta didik terhadap nilai-nilai mulia untuk diterapkan dalam sikap, ucap dan tindakan sehari-hari. Sehingga tekanan utama mata pelajaran ini lebih pada wilayah aplikasi atau penerapan nilai-nilai luhur dalam keseluruhan hidup dan kehidupan peserta didik.

Aplikasi teori konstruktivistik bila masuk ke dalam pembelajaran PAI khususnya di bidang Fiqh, maka para peserta didik akan membentuk: (1) Peserta didik akan membangun atau mengkonstruksi pengetahuan tentang fiqh khususnya masalah shalat, dari hasil yang mereka dapatkan ketika mereka duduk di bangku Madrasah Ibtidaiyah, (2) Pembelajaran tentang ibadah shalat akan menjadi lebih bermakna karena peserta didik sudah mengerti walaupun masih ada juga yang belum tahu, namun dalam hal ini teori konstruktivistik yang diaplikasikan kedalam pembelajaran dapat menumbuhkan respons yang positif karena stimulus yang diberikan juga pengaruhnya lebih besar. (3) Strategi pembelajaran hukum fiqh lebih sempurna. Peserta didik dapat berinteraksi penuh dengan metode pembelajaran ibadah shalat, karena ibadah shalat tidak cukup hanya teoritis tapi juga harus dipraktekkan.

Aplikasi teori belajar konstruktivisme dalam pendidikan anak khususnya pendidikan agama islam adalah (1) Tujuan pendidikan menurut teori belajar konstruktivisme adalah menghasilkan individu atau anak yang memiliki kemampuan berfikir untuk menyelesaikan setiap persoalan yang dihadapi, (2) Kurikulum dirancang sedemikian rupa sehingga terjadi situasi yang memungkinkan pengetahuan dan keterampilan dapat dikonstruksi oleh peserta 
didik. Latihan memecahkan masalah selain itu seringkali dilakukan melalui belajar kelompok dengan menganalisis masalah dalam kehidupan sehari-hari dan, (3) Peserta didik diharapkan selalu aktif dan dapat menemukan cara belajar yang sesuai bagi dirinya. Guru hanyalah berfungsi sebagai mediator, fasilitor, dan teman yang membuat situasi yang kondusif untuk terjadinya konstruksi pengetahuan pada diri peserta didik.

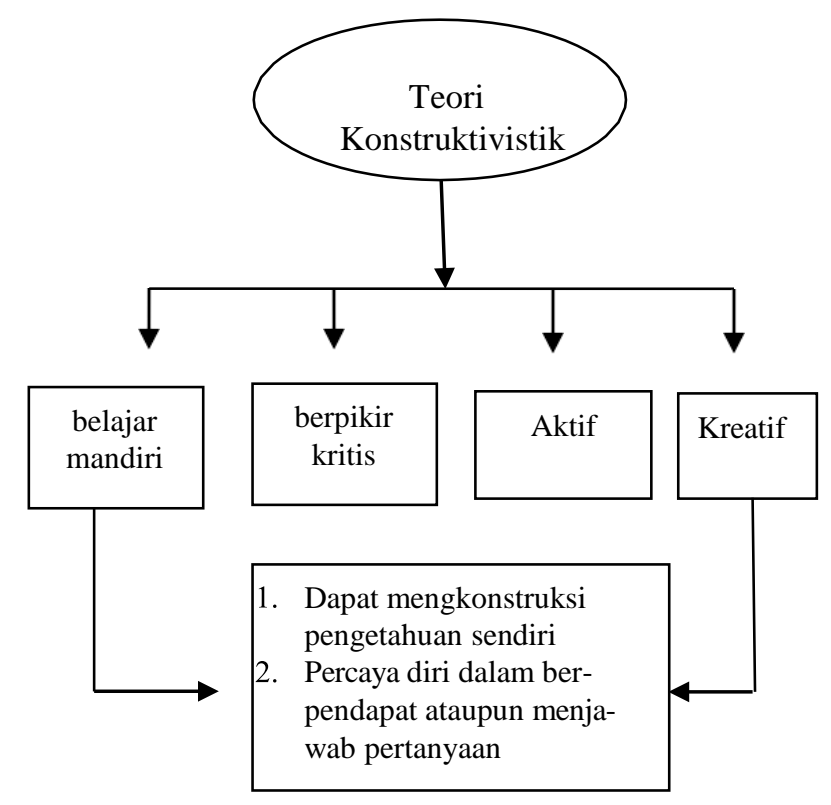

\section{Siswa Dapat Belajar Mandiri}

Belajar mandiri merupakan belajar yang didasari oleh pemikiran yang dikonstruksi oleh diri sendiri. Kemandirian belajar diperlukan dalam sis-tem pendidikan dikarenakan agar tercapainya suatu tujuan pembelajaran yang dapat menekan peserta didik aktif dalam mengembangkan potensinya. Kemandirian belajar seseorang dapat ditunjukkan dengan adanya kepercayaan diri akan kemampuan dalam menyelesaikan berbagai macam permasalahan (persoalan) yang ada selama kegiatan berlangsung, tanpa bantuan dari orang lain dan juga tidak dikontrol pengambilan keputusannya dalam menyelesaikan permasalahan (persoalan). Sama halnya dengan pernyataan Desmita bahwa, kemandirian belajar peserta didik muncul ketika peserta didik menemukan diri pada posisi kepercayaan diri yang meningkat. Oleh karena itu, menurut Nurhayati adapun ciri-ciri pembelajaran yang memiliki kemandirian belajar, yaitu, (1) siswa mempunyai tanggungjawab, (2) memiliki keyakinan, (3) tidak mudah terpengaruh oleh orang lain, (4) apabila men- jumpai masalah berusaha untuk memecahkanya sendiri, (5) dapat memanfaatkan waktu dengan baik (Pratiwi \& Laksmiwati, 2016).

Uraian di atas dapat kita ketahui bahwa peserta didik yang memiliki kepercayaan diri yang tinggi, akan mampu mengelolah pembelajarannya sendiri dengan baik tanpa bantuan dari orang lain dalam menemukan dan memecahkan persoalan yang ada. Untuk itu dalam hal ini kemandirian peserta didik dalam proses pembelajaran sangat relavan dengan teori pembelajaran konstruktivistik yang dikenal sebagai teori pembelajaran modern. Teori pembelajaran konstruktivistik menekan peserta didik agar mengkonstruksi sendiri pengetahuan yang di perolehnya sebagai bukti bahwa peserta didik tersebut sudah dapat berpikir kritis, kreatif dan aktif dalam pembelajaran yang sedang berlangsung. 
Tabel 1. Daftar Nilai Ulangan Harian Siklus I

\begin{tabular}{|c|c|c|}
\hline Nilai & Frekuensi & Presentase \\
\hline $0-40$ & 0 & $0.0 \%$ \\
\hline $41-69$ & 14 & $33.3 \%$ \\
\hline $70-100$ & 7 & $66.7 \%$ \\
\hline Jumlah & 21 & $100 \%$ \\
\hline
\end{tabular}

Tabel di atas dapat kita lihat terdapat 7 siswa atau 33,3\% yang mendapat nilai antara 41 - 69, dan 14 siswa atau 66,7\% yang mendapat nilai antara $70-100$. Dengan ketentuan nilai KKM 70, dapat disimpulkan jika pencapaian prestasi nilai 70 - 100, maka prestasi belajar siswa telah meningkat dari $35 \%$ menjadi $66,7 \%$. Indikator pencapaian siklus I sebesar $85 \%$ atau lebih belum mencapai target, maka akan dilanjutkan ke Siklus II. Selain itu, dari proses wawancara diperoleh kesimpulan bahwa beberapa siswa menjadi bersemangat dalam belajar Pendidikan Agama Islam, karena pelaksanaan kegiatan belajar Pendidikan Agama Islam dengan Teori Konstruktivisme ini dilaksanakan dengan langsung secara mandiri oleh siswa, dan melaksanakan kegiatan bersama kelompok sehingga lebih ringan. Meskipun masih terdapat kendala-kendala.

Tabel 2. Daftar Nilai Ulangan Harian Siklus II

\begin{tabular}{|c|c|c|}
\hline Nilai & Frekuensi & Presentase \\
\hline $0-40$ & 0 & $0.0 \%$ \\
\hline $41-69$ & 2 & $9.5 \%$ \\
\hline $70-100$ & 19 & $90.5 \%$ \\
\hline Jumlah & 21 & $100 \%$ \\
\hline
\end{tabular}

Tabel di atas dapat kita lihat terdapat 2 siswa atau 9,5\% yang mendapat nilai antara 41 69, dan 19 siswa atau 85\% yang mendapat nilai antara 70 - 100. Dengan ketentuan nilai KKM 70, dapat disimpulkan jika pencapaian prestasi nilai 70 - 100, maka prestasi belajar siswa telah meningkat dari $66,7 \%$ menjadi $90,5 \%$. Dengan $90,5 \%$ maka telah tercapai indicator pencapaian siklus II sebesar yang $85 \%$ atau lebih, maka tidak perlu dilanjutkan ke Siklus III. Selain itu, dari proses wawancara diperoleh kesimpulan bahwa beberapa siswa menjadi bersemangat dalam belajar Pendidikan Agama Islam, karena pelaksanaan kegiatan belajar Pendidikan Agama Islam yang menggunakan Teori Konstruktivisme ini dilaksanakan dengan secara baik bersama kelompok menjadikan mereka lebih rileks dan ringan dalam mengerjakan laporan kegiatan. Meskipun masih terdapat kendala-kendala seperti yang telah diuraikan dalam laporan observasi.

\section{Siswa Berpikir Kritis}

Berpikir kritis merupakan konsep untuk merespon sebuah pemikiran yang dapat peserta didik terima (Syahrul, 2018; Syahrul \& Wardana, 2017). Respon tersebut melibatkan kemampuan mengeval-uasi secara sistematis. Berger dan Luckmann berpandangan bahwa pembelajaan konstruktivisme memandang belajar itu merupakan proses berfikir kritis untuk mengkonstruksi pengetahuan yang telah diterimanya melalui proses objektif pengetahuan. Menurut Bloom berpikir kritis memiliki arti yang sama dengan tinggkat berpikir yang lebih tinggi dalam hal ini juga Bloom mendaftarkan enam tingkat dari tingkatan berpikir kritis yang paling sederhana sampai yang paling kompleks daftar tersebut mulai dari pengetahuan dan bergerak keatas menuju penguasaan, aplikasi, analisis, sintesis dan evaluasi (Rahayu \& Cintamulya, 2019: 8-14).

Suparno menjelaskan di kalang konstruktivis berpikir kritis yang baik adalah lebih page 6 | An-Nuha: Jurnal Pendidikan Agama Islam 
penting dari pada mempunyai jawaban yang benar atas suatu persoalan yang sedang dipelajari. Siswa yang mempunyai cara berpikir yang baik dalam arti bahwa cara berpikirnya dapat digunakan untuk menghadapi suatu fenomena baru akan dapat menemukan pemecahan (persoalan) dalam menghadapi masalah yang lain. Oleh karena itu, mengajar dalam konteks ini adalah membantu seseorang berpikir secara benar dengan membiarkannya berpikir sendiri.

Aktivitas dari pembelajaran di atas dapat kita ketahui bahwa dalam melaksanakan proses pembelajaran dengan menggunakan teori pembelajaran konstruktivistik pada mata pelajaran sosiologi, memerlukan tahap-tahap pembelajaran yang cukup rumit dan memerlukan waktu yang cukup lama agar peserta didik dapat menerima dan memahami apa yang guru berikan. Hal ini agar dapat memperoleh cara berpikir kritis pada diri peserta didik sendiri (Syahrul, 2018).

Dari penelitian yang dilakukan oleh Hermanto (2016) mengungkapkan bahwa aktivitas peserta didik di SMA Negeri 42 Jakarta mengalami peningkatan dengan menggunakan pendekatan konstruktivisme dalam pembelajaran. Adapun aktivitas pembelajaran yang dilaksanakan seperti merumuskan masalah, memberi argument atas pernyataan teman, memberi tanggapan, berdiskusi dengan teman, melakukan deduksi, melakukan induksi, menganalisis, evaluasi dan mengambil kesimpulan semuanya mengalami peningkatan. Dikarenkan semakin banyak peserta didik berpartisipasi dalam pembelajaran seperti yang sudah dijelaskan di atas hal tersebut dapat menunjukan bahwa berpikir kritis peserta didik mulai meningkat.

\section{Siswa Kreatif}

Siswa kreatif merupakan siswa yang mampu menciptakan hal-hal baru dalam belajarnya baik kemampuan dalam mengembangkan informasi yang di peroleh dari pendidik (guru) di dalam proses belajar mengajar yang dapat berupa pengetahuan sehingga dapat membuat perpaduan yang baru (Syahrul, 2020). Menurut Munandar berpikir kreatif siswa sebagai kemampuan untuk melihat bermacam-macam untuk menyelesaikan suatu masalah. Menurut Munandar kemampuan berpikir kreatif siswa meliputi empat kriteria, antara lain kelancaran, kelenturan, keaslian dalam berpikir dalam mengembangkan gagasan (Larasati, 2020).

Munandar mengemukakan ciri-ciri dari siswa kreatif sebagai berikut: (a) kelancaran berpikir, yaitu kemampuan untuk menghasilkan banyaknya ide yang keluar dari pemikiran seseorang secara cepat, (b) keluwesan berpikir, yaitu kemampuan yang dapat memproduksi pertaanyaan-pertanyaan dan ja- waban-jawaban atau pertanyaan yang bervariasi serta mampu menggunakan bermacam-macam pendeka- tan atau cara pemikiran, (c) originalitas, yaitu kemampuan dalam mencetus gagasan unik ataupun mencetus gagasan asli, (d) elaborasi, kemampuan mengembangkan gagasan secara detail dari suatu objek sehingga menjadi lebih menarik (Maskur, Waluya, \& Rochmad, 2012).

Uraian di atas dapat kita ungkapkan bahwa kemampuan kreatif siswa merupakan hal yang telah dimiliki sejak lahir yang harus dikembangkan dan dilatih. Salah satu teori pembelajaran yang dapat dijadikan sebagi alternatif dalam pembelajaran agar siswa lebih aktif dalam belajarnya yaitu dengan menggunakan teori pembelajaran konstruktivisme.

\section{Siswa Aktif}

Teori pembelajaran konstruktivistik merupakan teori yang mendorong siswa agar lebih aktif dan memahami apa yang telah diberikan oleh guru. Dalam pembelajaran sosiologi dengan teori pembelajaran konstruktivistik, guru mengapresiasikan saat pembelajaran awal dengan menyinggung kembali materi yang sudah dijelaskan atau dipelajari oleh siswa sebelumnya. Adapun pernyataan dari teori konstruktivistik Piaget bahwa pengetahuan tidak dapat ditransfer begitu saja dari pikiran guru kepada pikiran peserta didik. Piaget dalam hal ini memandang 
bahwa setiap individu memiliki kemampuan untuk mengkonstruksi sendiri pengetahuanya dengan jalan berinteraksi cara terus-menerus dengan lingkungannya. Gintings menjelaskan keterkaitannya dari teori ini yaitu menolak bahwa ilmu pengetahuan adalah suatu yang dapat ditransfer. Pernyataan Piaget dalam hal ini berbeda dengan pernyataan yang dikemukakan oleh pakar filosofi konstruktivistik yaitu Vygotsky yang mana Dia lebih suka menyatakan bahwa teori pembelajaranya sebagai pembelajaran kognisi sosial (social cognition). Artinya bahwa kebudayaan merupakan penentu utama bagi pengembangan manusia. Oleh karena itu, perkembangan peserta didik dipengaruhi banyak maupun sedikit dipengaruhi oleh kebudayaan baik dari lingkungan keluarga tempat dimana anak (peserta didik) tersebut berkembang (Prastowo, 2015).

Pernyataan dari kedua pakar konstruktivistik di atas dapat kita pahami bahwa pembelajaran dengan menggunakan teori konstruktivistik dapat dikonstruk (dibangun) oleh keaktifan peserta didik untuk mendengar dan memahami dari pendidik (guru) dengan mengaitkan pengetahuan awal atau pun pengalaman yang telah dimiliki peserta didik. Pengetahuan yang dimiliki oleh peserta didik juga dibangun dan dipengaruhi oleh kebudayaan (kebiasaan) yang dilihat dan dilakukan terus menerus oleh siswa di lingkungan di mana peserta didik berinteraksi di lingkungannya tempat peserta didik tersebut berkembang.

Guru memotivasi (apresiasi) peserta didik agar aktif selama proses pembelajaran sosiologi. Dalam pembelajaran agama islam, guru hanya mediator untuk memberi arahan dalam berlangsungnya proses pembelajaran dan di sini juga guru memberi tugas yang jelas saat melakukan pembelajaran dalam kerja kelompok. Pernyataan ini sama dengan pernyataan dari Waseso menyatakan bahwa posisi guru pedidikan agama islam dalam berlangsungnya pembelajaran hanyalah mediator bagi pelajar (peserta didik) (Syahrul, Arifin, Datuk, Almu, \& Ramlah, 2019).

Berdasarkan hasil analisis pengelolahan pembelajaran dengan menggunakan konstruktivisme dalam setiap pembelajaran dapat disimpulkan bahwa penerapan konstruktivistik di dalam pembelajaran sangatlah baik atau dapat membawa pengaruh yang positif bagi peserta didik dan dapat meningkatkan hasil belajar. Pembelajaran dengan menggunakan konstruktivisme dapat lebih cepat meningkatkan pemahaman dan juga perkembangan daya berpikir kritis peserta didik dengan cara yang kreatif yang digunakan oleh guru untuk mentransfer pengetahuan pembelajaran kepada siswa sehingga hasil belajar lebih meningkat dari penerapan model pembelajaran konvesional lainya.

\section{V.Simpulan}

Berdasarkan pemaparan di atas dapat di simpulkan yaitu pada dasarnya teori konstruktivisme disini diartikan sebagai suatu pendekatan di mana siswa harus secara individual menemukan dan menstransformasikan informasi yang kompleks, memeriksa informasi dengan aturan yang ada dan merevisinya bila perlu. Konsep dasar konstruktivisme merupakan suatu unsur dimana seseorang dapat membina pengetahuan dirinya secara aktif dengan cara membandingkan informasi baru dengan pemahamannya yang sudah ada.

Teori pembelajaran konstruktivistik dapat meningkatkan hasil belajar. Dengan teori pembelajaran konstruktivistik, peserta didik tidak hanya menerima materi pembelajaran dari guru, namun peserta didik juga yang berusaha untuk menggali dan mengembangkannya sendiri. Dalam hal ini, teori pembelajaran konstruktivisme tidak hanya menghasilkan dan meningkatkan pengetahuan saja, tetapi teori ini juga dapat meningkatkan keterampilan berpikir kritis peserta didik. Teori pembelajaran konstruktivistik mampu meningkatkan hasil belajar peserta didik. Hasil belajar diperoleh dari kemampuan peserta didik dalam memecahkan masalah dalam soal yang dikerjakan secara mandiri maupun kelompok. Kemampuan peserta didik untuk memecahkan 
masalah tersebut dapat dilihat dari kemampuanya dalam menjelaskan hasil pekerjaanya di depan kelas dan menjawab pertanyaan-pertanyaan yang diajukan oleh teman-temanya. Oleh karena itu, pembelajaran dengan teori konstruktivistik sangat menekan pada keaktifan dan keterlibatan peserta didik dalam proses pembelajaran sebagai pening- katan hasil belajar yang optimal.

Aplikasi teori belajar konstruktivisme bila diterapkan di kelas akan terbentuk: a) Mendorong kemandirian dan inisiatif siswa dalam belajar. b) Guru mengajukan pertanyaan terbuka dan memberikan kesempatan beberapa waktu kepada siswa untuk merespon. c) Mendorong siswa berpikir tingkat tinggi. d) Siswa terlibat secara aktif dalam dialog atau diskusi dengan guru dan siswa lainnya. e) Siswa terlibat dalam pengalaman yang menantang dan mendorong terjadinya diskusi. f) Guru memberikan data mentah, sumber-sumber utama, dan materi-materi interaktif.

\section{Referensi}

Bada, S. O., \& Olusegun, S. (2015). Constructivism learning theory: A paradigm for teaching and learning. Journal of Research \& Meth- od in Education, 5(6), 66-70.

Baharun, H. (2015). Penerapan Pembelajaran Active Learning Untuk Meningkatkan Hasil Belajar Siswa di Madrasah. PEDAGOGIK: Jurnal Pendidikan, 1(1).

Forsey, M. (2015). Learning to Stay? Mobile Mo- dernity and the Sociology of Choice. Mobilities, 10(5), 764-783.

https://doi.org/10.1080/17450101.2014.927 202

Hermanto, R. (2016). Peningkatan Berpikir Kritis pada Mata Pelajaran Sejarah Melalui Pendekatan Pembelajaran Konstruktivistik. Jurnal Pendidikan Sejarah, 5(1), 1-9. https://doi.org/10.21009/JPS.051.01

Insriani, H. (2011). Pembelajaran Sosiologi yang Menggugah Minat Siswa. KOMUNITAS: International Journal of Indonesian Society and Culture, $\quad 3(1)$. https://doi.org/10.15294/komunitas.v3i1.23 00

Killian, M., \& Bastas, H. (2015). The Effects of an Active Learning Strategy on Students' Attitudes and Students' Performances in Intro- ductory Sociology Classes. Journal of the Scholarship of Teaching and Learning, 15(3), 53-67. Retrieved from https://eric.ed.gov/?id=EJ1064430

Kusuma, A. S. H. M., \& Nisa, K. (2019). Hub- ungan Keterampilan Metakognitif Dengan Hasil Belajar Mahasiswa S1 PGSD Univer- sitas Mataram Pada Pembelajaran Menggunakan Pendekatan Konstruktivisme. Jurnal Ilmiah Profesi Pendidikan, 3(2). https://doi.org/10.29303/jipp.v3i2.23

Larasati. (2020). Pengaruh Media Peta Berbasis Kon-struktivisme Tehadap Hasil Belajar IPS Siswa Sekolah Dasar. Elementari Edukasia, 3(1).

Maskur, A., Waluya, S. B., \& Rochmad, -. (2012). Pembelajaran Matematika dengan Strategi Icare Beracuan Konstruktivisme untuk Meningkatkan Kemampuan Berpikir Kreatif Materi Dimensi Tiga. Journal of Primary Education, $\quad 1(2)$. https://doi.org/10.15294/jpe.v1i2.787

McCourt, D. M. (2016). Practice theory and Relationalism asTthe New Constructivism. International Studies Quarterly, 60(3), 475-485. 
Moleong, L. J. (2019). Metodologi penelitian kualitatif.

Novia, T. R., \& Kusumo, E. (2013). Penerapan Model Pembelajaran Konstruktivisme Berbantuan Concept Map untuk Meningkatkan Hasil Belajar Kimia pada Siswa SMA. Jurnal Inovasi Pendidikan Kimia, 7(1). Retrieved from https://journal.unnes.ac.id/nju/index.php/JIP K/article/view/4410

Prastowo, A. (2015). Pembelajaran Konstruktivistik Scientific untuk Pendidikan Agama di Sekolah/Madrasah. Jakarta: Raja Grapindo.

Pratiwi, I. D., \& Laksmiwati, H. (2016). Kepercayaan Diri dan Kemandirian Belajar Pada Siswa SMA Negeri "X". Jurnal Psikologi Teori dan Terapan, 7(1), 43-49. https://doi.org/10.26740/jptt.v7n1.p43-49

Putra, R. E. (2018). Peningkatan Hasil Belajar Siswa Menggunakan Pendekatan Konstruktivisme dalam Pembelajaran IPS di Ke- las IV SD Negeri 51/II Desa Paku Aji Kecamatan Tanah Sepenggal Lintas Kabu- paten Bungo. Jurnal Muara Pendidikan, 3(2), 124-136. Retrieved from http://ejournal.stkipmmb.ac.id/index.php/mp/article/view/83

Rahayu, R., \& Cintamulya, I. (2019). Analisis Kemapuan Berpikir Kritis Siswa SMP berbasis Gaya Kognitif melaui Pembelajaran TPS (Think Pairs Share) dengan Media Poster. Bioedukasi: Jurnal Pendidikan Biologi, 12(1), 8-14. https://doi.org/10.20961/bioedukasi- uns.v12i1.27356

Ramadhani. (2012). Pengaruh Model Pembelajaran Konstruktivisme 5E Terhadap Hasil Belajar di SMA Laksamana Martadinata. Jurnal Pendidikan Fisika, 1 (1), 50.

Satori, \& Komariah. (20. 12). Metodologi Penelitian Kualitatif. Bandung: Penerbit Alfabeta. 